\title{
銅合金の応力腐食割れに関する確率*
}

\section{H. Thompson**}

\section{緒}

腐食は，全面腐食と局部腐食の二つに，大きく大別す ることができる。全面腐食は，腐食を取扱う技術者によ って，普通は，大きな問題ではない。というわけは，そ れが重大でないからでなく，その重大性が，かなり良く 子知できるからである。たとえば，銅が塩化第二鉄溶液 中で全面的に腐食されるという事実は，銅が，その溶液 を取扱うのに使用しうることを意味しないが，銅が，非 常に速く腐食されるので，腐食速度が，十分に予知でき ることを意味しているにすぎない。

局部腐食は，大変不思議なものであり，普通やっかい なものである。局部腐食の最も一般的な形式は，孔食と 割机である。金属の表面のある範域内に，その金属を貫 く 1 個の孔食がある場合に，金属表面の，その範域内の かなりの部分が，本質的に腐食されないということは， ざして重要なことではない。そういうときには腐食の全 量は大変少ないだろらが，試片は破損してしまう。割れ は一層悪質なものだろう。腐食される量が測りえられぬ ほど少量でも，破損は，急激に，破滅的に起る。腐食割 れには, 二つの型があり, 一つは腐食疲れ, 他は応力腐 食割れである。

\section{応力腐食割れ}

応力腐食割れは，ほとえどあらゆる型の金属に，発生 する。鋼にも，ステンレス鋼にも，アルミニウム合金に も，マグネシウム合金にも，金合金において市ら発生す

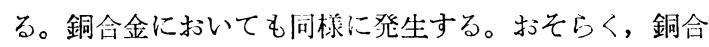
叙注この点に関しては, 最も評判の悪いものだろう。と いらわけは, 黄銅の時期割れは, ステンレス鋼が発明さ れる前に, 既に知られており，その当時はアルミニウム やマグネシウムは元素の周期率表ではまだ空白だったの だ。しかし，この点に関しては銅合金に他の合金元素を 加えることにより，かなり進歩してきた。

応力腐食割れについては，非常に多くのことが知られ てれり，それを説明するために，幾多のすぐれた理論が 提出された。けれども，もうすっかり知りつくされてい ると考えられているのではなく，おそらく，科学者は， ぞのようにして, なぜ, 割れが起るのかを考え続けるだ ろう。実用的な見地からは応力腐食割れは非常に良く理 解されている。その防止方法などは当り前の知識であ

* 訳者 中山忠行 早稲田大学第一理工学部金属工学科

** Corrosion Research Lab., American Brass Co. Waterbury, Conn.

(原文) Probability as Related to Stress Corrosion Cracking of Copper Alloys. Corrosion, Vol. 15, No. 8, 433 t 436t (1959) Aug.
る。

忍力腐食割れが応力と腐食という，二つの同時に作用 する要因の結果として起るということは明らかなことで ある。これに 3 番目の要因として，時間が加えられるべ きである。なぜなら応力腐食割れは突然に発生するけれ ぞも，突然の破損の前に，末ず潜伏期があり，続いて割 れの進行する期間があるからである。応力は残留してい たものか，またはそのときかけられた応力だろう。残留 応打とは, 先に行なわれた, 冷問加工や, ある種の変形 以来，金属の内に残っている応打である。負荷応力之 は，負荷のある間だけ存在し，それにより生じる応力で ある。応力が引張りでざえあれば，あらゆる型の応力が 応力腐食割れの原因となるだろら。圧緛応力は応力腐食 割れの原因とならないばかりか, 引张応力が金属の内部 に存在するような場合でも, 表面の圧縮応力は応力腐食 割れを防ぐ傾向すらある。

念打腐食割れを発生する腐食棛はなかなか興味のある ものである。各々の合金系は割れを発生さす，たぶ一つ の腐食剂を持つような特定の傾向がある。これについて は銅合金は独特のものである。その弱点はアンモニヤで ある。ある条件の下では液体金属もまた，銅合金に割れ， を発生させるが，その機構は異なったものであり，実用; 的な重要性も異なっている。アンモニヤは銅合金の応力 腐食割れには，欠かすことのできないものといえよう. がこういう表現が適当でないというなら，次のように。 一般化する必要がある。「銅合金の応力腐食割れにとっ. てアンモニヤが必要であると一般に信じられている。」 実際には，この事実はたやすくは証明されない。たとえ. ば $\mathrm{CO}_{2}$ に富んだ父体中で，もし応力腐食割れが起る上 すると, $\mathrm{CO}_{2}$ ガスが割れの原因であると容易に考えら れてしまうだろう。しかし， $\mathrm{CO}_{2}$ が原因であることを証 明し，またその父体中にナンモニヤが全くないことを証 明するのは困難である。

フンモニヤが重大だと信じられている本当の理由は, フンモニヤが非常に急速に割机を起させるからである。 蓋のある容器の中に高応打をかけられた, 黄銅の部品を つるしておくという試験がある。四つの異なった各々の 容器の底には多少の水が入っており, その水は, $\mathrm{CO}_{2}$, $\mathrm{SO}_{2}, \mathrm{H}_{2} \mathrm{~S}, \mathrm{NH}_{3}$ の異なった気体で各々飽和されている。 その結果はアンモニヤ液上の三つの試片には, $16 \mathrm{hr}$ 以 内に割れが入った。硫化水素を飽和した液上の試片は 9 カ月目の終りに試片のうちの一つに割れが入ったが， 2 yr の終りになっても，これ以上の試片は割れなかっ た。 $\mathrm{H}_{2} \mathrm{~S}$ ガスが応力腐食割狄を起させたのかもしれない 
し，また容器の中の父体がフンモニヤで污染されていた のかもしれない。上もかく，アンモニヤは他の気体に比 ベて 400 倍も速く制れを生じきせる。

アンモニヤ単独では，しかし，十分な腐食郕とはなり えない。常温に打ける他のあら!るる型の腐食と同様に水 之空気が必要な要素でかる。銅合金に関する限り湿った アンモニヤ父体中では，ざっ上速く割れが発生する。

銅合金の心腐食割机が起る条件注，以上に述べたご とくである。すなわ方，金属は引張応力のもとになけれ ばならないし，生腐食戍之湿父之空気とに接触してい なければならない。さらに制れが起るなでに十分な時間 が必要だろうし，金風は応打腐食割れをを起しやすいもの でなければならない。時閒しいうのは枌違いに変化す る。 $5 \mathrm{~min}$ 以内のこ亡もあれば，何カ月もかりることも あり，さらに何年もかょることさえある。

\section{確率の適用}

近年，科学，工学の分野では活しえどすべてのものが 磼率で表現される。たとえば，方る物体を落下さす場合 それは大地にまで落らるだろう。もっと正しく表現する 之，ある物体が落下する場会，てれが大地にまで落らる 非常に高い確率が存在する。確率は割れが発生したり， しなかったりする理由を表現するのに有効なるのであ る。さて，一つの事象の起る雔率之，もう一つの他の事 象の起る確率がある場合, 両方が起りうる確率は, 各々 の二つの確率の積となる。

ここに，工学の分野からの簢単な実例がある。まず, 一つの操作孔老持った，间い内压を加けうる容器を設計 するとしょう。この孔の蓋は，4本のボルトで，安全が 計られる。ボルトは部当な引㖘䂈さを持つように作製さ れるが，いずれのボルトも正確に適当なものであること を証明するためには，破壊試験を行なう必要がある。そ うずれば，ボルトが使用に耐えら机ないこともわかる。 かくして，標本を検査しボルトのある割合のものは試験 され，いずれのボルトも適当な引張強さを持つような確 率が知られる。いま, 適当な引張強さ在持つ確率が 0.99 ごあると，いずれのポルトも適当な强さを持たない確率 は 0.01 すなわち 100 本の内の 1 本だけとなる。では 無作為に選ばれた 2 本のボルトが，要求される強さを持 たないだろう上いう確率はごれくらいだろうか。それは 二つの確率の積之なる。すなわら 1 万の内の一つであ る。3 本なら 100 万の内の一つであり，4 本なら 1 億 の内の一つとなる。だから，操作孔の蓋が，4 本のボル トの破損のためにすっっんでしまうだろう確率は， $1 \times 10^{-8}$ であると結論しうる。

応力腐食割れの発生する確率も同㥞に洘えられるだろ う。良く知られている銅台金の応力腐食割れの要因は, 前述のごとく, アンモニヤ, 湿父, 空気, 応力, それに

合金の割れに対する感受性である。これらのものがか か なりの程度に存在与る場合，言い換えると，その政率が 高い場合には割れの起る確率も高くなるだろう。このこ とは数学的に法次のように表現できる。

$$
1 / \mathrm{T}=\left(\mathrm{NH}_{3}\right)\left(\mathrm{H}_{2} \mathrm{O}\right) \text { (Air) (S) (Alloy) }
$$

ここで (T) は割れの発生するまでの時間, $\left(\mathrm{NH}_{3}\right)$ は フンモニヤの割合， $\left(\mathrm{H}_{2} \mathrm{O}\right)$ は水の割合，(Air) 注空父 の制合，(S) は灾力レベル，(Alloy）珨金の, 応力腐 食割れに対す西感受性定各々表わしている。

これらのものは，確率として表現するこ上ができ， $\left(\mathrm{NH}_{3}\right)$ 注, 高濃度のアンモニヤが存在する確率堂きす。 かくして方程式洼次のように装けるだるう。

$$
\mathrm{P}_{\mathrm{C}^{\mathrm{HN}} \mathrm{d}={ }_{3}} \cdot \mathrm{P}_{\mathrm{H}_{2} \mathrm{O}} \cdot \mathrm{P}_{\mathrm{Ai} \mathrm{r}} \cdot \mathrm{P}_{\mathrm{S}} \cdot \mathrm{P}_{\mathrm{Alloy}}
$$

ただし $P_{\mathbf{C}}$ は制れの起るだるうという確率である。

\section{赤黄銅ハイプの破損}

次に述べるのは, 予知することのできない応力腐食制 れの例である。赤黄銅は, 态刀腐食割れに対する抵抗性 が良い。だから，焼鈍された赤黄銅のパイプは，配管装 置の中で応力腐食割れを起式とは考えられない。空父上 湿父が存在しても，テンモニヤが多くないと思われる場 合に圭，浾黄銅のパイプが念力腐食割礼老起すという苦 情を受泛ることは，まずないことであった。実験に上っ て次の上うなことが明らかしなった。

1）配管者がハイイプ敷設中に管を曲洔たため残留忘小 が生じた。

2) イイ プは, 獣毛 のフェルト で被復され 避暑用の别 荘の縁の下 に敷設され た。フェル トの中の穼 素化合物汇 分解してア ンモニヤと なった。

3) ำ プの表面に 古，妿名 は被復の外 側にも，適 当な蒸父に よる遮断は 起らなかっ た。

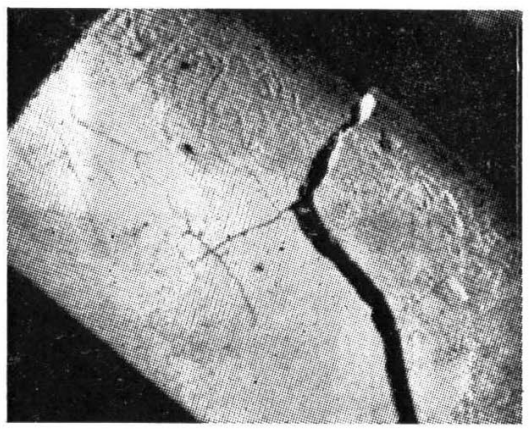

第 1 図赤黄銅パイフ 外表面の重裂に生意 $\times 1.6$

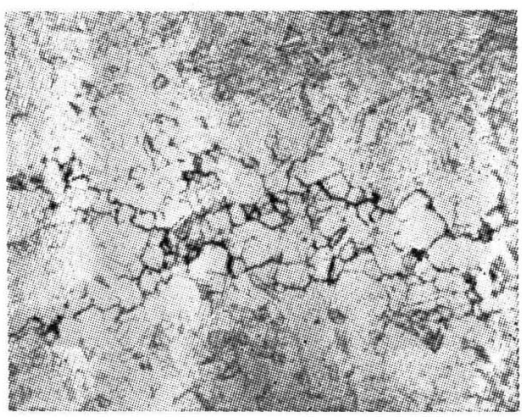

第 2 図赤黄銅パイフの粒間亀裂を通 っての縦方向断面 $\times 110$ 
十分なアンモニヤ, 湿気, 空気, 応力が存在し, それ らが割れの発生する確率を高めるようなものである場合 には，合金の特性として割れの起りにくさも圧倒されて 破損してしまった。第1図は割れの入った管の外周表面 を示し，第 2 図は絴方向断面の拡大図である。クラック が，結晶粒内を貫いていることに注意すること。

\section{水道管用銅管の破損}

もう一つの場合は，きわめて類似したものであったが ずっと起りにくいものだった。含燐銅は，応力腐食制れ に対し，すくれた抵抗性をもっている。冷間で引抜かれ た水道管用の銅は黄銅加工機の標準製品なのだが，この 合金が応力腐食割れに対して，非常に良い性質をもって いるので, 垥間引抜の結果生じた内部応力について, 何 の心配もなかった。実際，応力はその合金の機械的性質 のために，モ゙っらかというと高くはない。

さて，問題の管はトンネルの中に敷設されたもので， 獣毛のフェルトで被覆されていたってしてフェルトの被 覆の外周には適当な蒸気の遮断物があった。しかも応力 を除いて，すべての確率は低かった。しかし，まだ説明 されない何らかの原因で被覆の一部が需れていた。たぶ

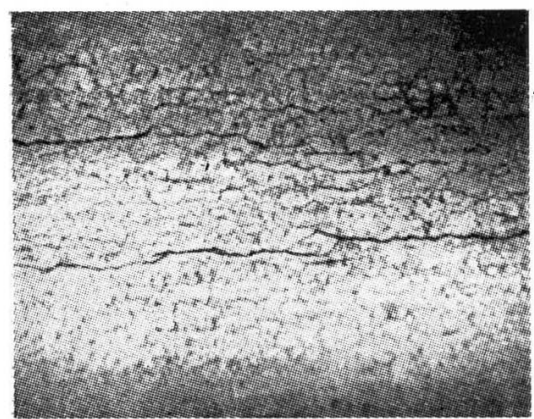

第 3 图 含りン銅管 亀裂は外表面に示されている

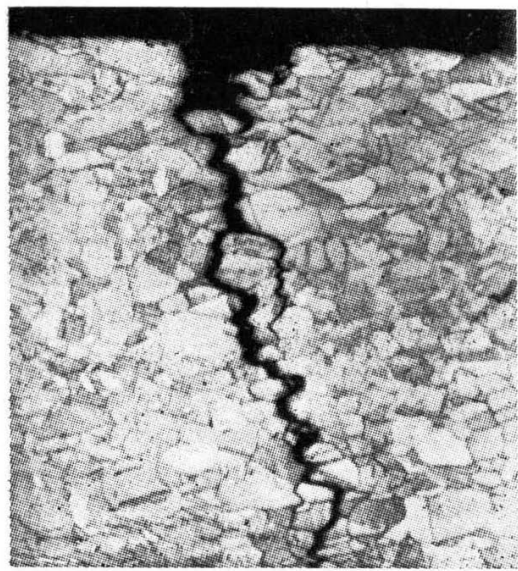

第4图含りシ銅管の亀裂を通じ ての緃方向断面 $\times 90$
え敷没中に

そうなった の片う。 ともかく, フェルトの 中の窒素化 金物の分解 により強臭 発子るに 十分和丁ン モ二十が生 成した。市 くして， ンモニヤ， 湿父空父, 応力等の確 率はすべて 変化した。 合金の腐食 に対する感 受性龙除い た， すべて のものが, 応力腐食割 れを促進す るようにな り，こ虬ら
のものが，合金の腐食抵抗に，打ちかってしまった。第 3 図は割れの入った管を示し，第 4 図は割れの縦方向の 切断面である。この管の破損の理由に関しての推論法， たぶ被覆の濡れた個所のみに制れが発生したという事実 により実証された。被腹が取り去られたとき,管は全面に わたって光沢を持って扣り，清浄なるここがわかった。 これらの二つの実例は，応磁食割れを避けようと寺る ときに，割れの発生を予知することのできない場合をる 検討する必要のあることを示している。

\section{0-30 キュプロニッケルの破損}

ここに異なった型の実例がある。30\% Ni のキュプロ ニッケルは応力腐食割れに対し,すぐれた抵抗性交持っ ている。これには実用上の破損の経験から，応力腐食制 れはほとえどないといいうる。ある実験室の試験で㲺， 70-30 キュプロニッケル管を大きな断面縮小率を与える ベく, Sinking 法で引抜いた。この方法は外周表面に非 棠に大きな引張応力を発生さす。ところで，数 $\mathrm{ft}$ の管 が実験公の棚に置かれておったのだが，割合短い期間 (9 カ月）の挠に，管に端から端末で割れの入っていること がわかった。確率の小さかった二つのものを除いた， す ベての確率が割れを起させるべく㗢いた。また管は名目 上乾燥していた。実験室の大弎中には，疑いもなく，あ る量のアンモニヤがあったが，てれも非常に多いものだ はなかった。実際には貯蔵期問中, 幾日かの間, 工湯は ストライキで閉睑され，实験室も使用されて抢らかっ た。

この管では応力が非常に大きかったので，腐食剂がな かったことも，割れに対するすぐれた性質も，相殺して しまったというのが唯一の合理的絬論である。繰返えナ ようだが，次のようなことがいえるわけである。破損の 確率は割れの発生を促す要因之関連のある数種の碓率の 積である。

\section{冷 却 管}

確率を意味する数を書き表わすことは実際上不可能で あるが，確率という考え方は，ある特別な目的に合う合 金を選ぶ上で，しばしば得難いものである。蒸気発生装 置で使われるような，外殼と管からなる簡単な冷却器の 佮却管は，めったに応力腐食で割れはしない。幾つかの 破損も非常に多く使われている管に比べたら物の数だは ない。

ごく普通の冷却管用合金であるアドミラルティ黄銅と フルミ黄銅は応力腐食割れに対しては弱い。これら疑 縮蒸気で常に濡れている。また，第二鉄の腐食を防ぐた めボイラー給水にフンモニヤかアミンを加えるので, ア ソモニヤの濃度は多少高い。五つの要因のうち三つのも のの確率は大きい。それで応力は低下させ,烧鈍された管 が使用されるが，配管のときに残る応力や使っている亡 
きにか、る応打子想より大きいらしい。また振動がた ぶえあるので周期的贱げの応力がからり，そのために， 応力腐食一疲れ㓶れをおこす。応力は管が沢山集るため に生じるのかもしれない。管が沢山集るとときどき管の シートの内側の縁をてえて膨脹し，そのために，内部応 才尼持った縁が尘ずる。操作中に管が偶然に叫んだり曲 がったりすることもまた応技生ぜしめるであろう。

5 番目の要风、空気であるが，事实上多くの冷却器で 挝存在しないだタっう。普通には勧父がないということは 冷却器の忍力腐出制れを防ぐことになる。というわけで 熱交換器は実用上の破揁で性能がきめられてきた。ある 石油粘製工場に二はストライキで閉ざされており，熱交換 器のう方の一つはある期閣中排水されて空のまつになっ た。ストライキの終りになって管が応力腐食でこわれて いるのがわかった。それもごくわずかのものではなく， かなりの制合のものだった。他の場合には，管の束は熱 交換器から取りはずされ，戸外に放置されておった。管 の外面の腐食生成物はてンモニヤ塭を含有しており空気 は湿っていた。その䋨果非常に多くの管に，応打腐食㓶 れが起った。しかしながら熱交換器から取りはずした直 後に管の腐食生成物を除去するなら，ある条件のももとて は割れが生じないことがわかった。使用中は空父が存在 しないために, 制机は起らず，戸外に放置してアンモ二 ヤがほとえどないときは割れなかった。確率のうちの一 つが小さいと，それは制れの原因とならず，他のものが 刘力を持つようになるわけである。

泠却管に孔があくと重大である。孔があくと海水であ るかもしれない暀却水が凝維してボイラーの給水となる だそう。ボイラー水としては海水は抢もしろくない。そ のときには泠却器は系列から外されて空にし閒放され

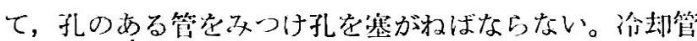
の応力腐食割れの川能性を避けるため，あらゆる努打が

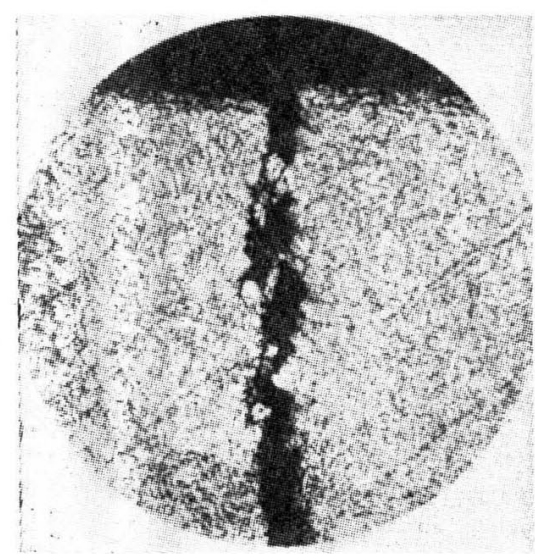

第 5 図キュプロニッケルー30\%管 の亀裂を通じての断面 $\times 45$
払われれは ならぬだタ 弓。 - 20 大変效果的 な方法は， $70-30 \neq$ プロニッケ ルの优用だ ろう。ここ にも，しか し確率が入 りこむ。 なわち、丁 ドミラルテ イ黄銅如万
ルミ黄銅の割れの起る碓率は非常に小さいのでキュプロ

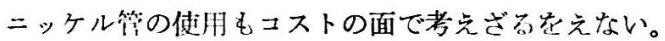

\section{ラセン状外枠の破损}

态力腐食制机の確率的特性を示すもう一つの例として 電球の口金やプラグフューズとして使わ机る，ラセン形 の成品を作る工場で発生するものがある。成型後に，こ れらの殼は非常に大きな内部応力を有し，しかもこれら は非常心応力腐食割れの起り易い合金である。成型後す ぐに内忘力を除くために燒鈍されるなら，使用時の応力 腐食制れに対する抵抗は改善される。この特殊な工場で は焼鈍炉はプレス工場とは別棟にあった。それで加工品 は工場の別棟へ移るのに，一たえ戸外に出なければなら なかった。金㺟の午後に作られたものは焼鈍室に運ば れ，焼鈍前，月曜の朝までそこにおかれた。普通この方 法で何らの悪影響も経験されないが，ある月曜の朝，非 常に多くの成品が割れていることがわかった。全成品が 割れたのではなく非常に多くのものが割れたのだ。その 原因は応力，空気および合金の割れに対する感受性の高 さの三つであることは確かだ。破損はプレスから灯のあ る部屋までの運搬中および週末中ずっと放置しておいた ことの両方に基因する。そのときに成品は温度変化をし て冷却した成品は温い湿気を含んだ空気と接し湿気の凝 縮が起った。他のすべての確率が大きければ割れを起さ すのにアンモニヤは多量には必要としない。ある場合に は，応力鹰食割れは生命をなくすような事故ともなるだ ろう。だから割れを防ぐための万善の策が必要である。

幸いにして悲劇にまで至らなかったある事故をこれか ら述べてみよう。それはコンクリートの煙突の上にあ り，ペンキ屋の台車のためのトロリーだった。この軌道 は bosun の椅子が煙突の周りをたやすく回れるように 支元以玌を ベく設司りさ れていた。 ネーバル黃 銅が使われ ていたのだ がこれは 応力腐食剖 れには弱い ものであ る。幸いに

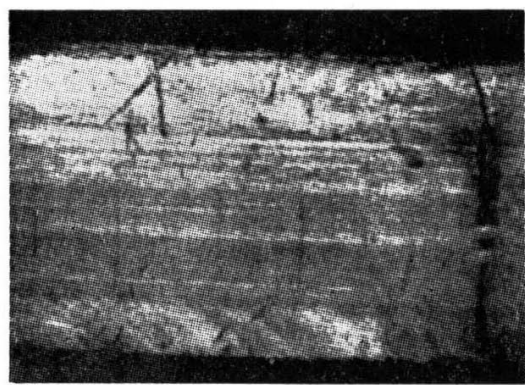

第 6 図ネーバル黄銅のペソキ屋 のトロリー $\times 3.5$

トロリーの割れは使用前に発見された。第 6 図にその様 子を示してある。

\section{焼鈍 $の$ 効 果}

設計に際し銅合金の応打腐食割れの起る確率をどうし て子知し，また使用中に発生した応㟲食割れを，どう して説明するかということを述べようとする努力が種ヶ 
な心秃てきた。このような啰含には制机の確㳯を最もた

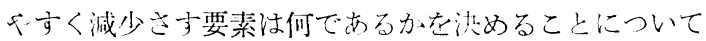
諭じられるべきである。汪とんどの埸们に焼鈍や念捈 去の燒鈍に残留応力安定な水準まで下げるための努力 かな心机ている。

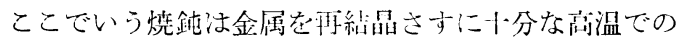
燒鈍である。応力を除去するための筧鈍は残留応力がな くなるような洫䓍で行なわ机る。しかし，その金属は可 練品しないし軟化も起らない。この二つの目的道成す るたんに，つ它り，応力を除去し，しかも硬さを減じな いたふに戦密な温度調節が必要である。正確な温废は各 ヶの埸今で異なり，合金の種類，冷間加工の程漫，試片 の大きさに左存さ机る。黄銅では $300^{\circ} \mathrm{C}$ 付近である。

护に述べた電球の口金のごとく，多くの場谷には残留 応力在除去するための焼鈍が実施される。ある啰合には

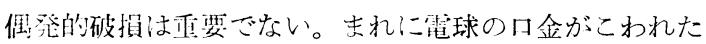
とこる、で，経済的には全く微々たるものだ。偶発的な破 扸を防ぐために间価な合金を使うことはむだなことだ

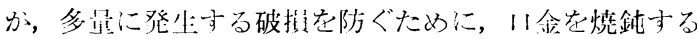
ととは効肾がある。

応方葆除去する焼鈍を策施することのできないものも いくらかある。猟銃用弾丸の外殼の黄銅製ベースはボー ル紙円阔に取付けられている。この埸合怘力が生じるが 令上紙をこがさずには金属を焼鈍できない。外殸のうち にある煙のでない粉末の分解でアンモニヤが生じるだる う。かっては，いくらかの応力腐食制れが焼くときに発 生した。最小の費用で，この確率を小さくするには，ど うしたら络いかさいうことに対して雬なの研究がなされ た。仁金老かえることは費用がかりり過ぎる。ワックス 壱塗のたり，シッカー老叙ったりすることは効果的だと わかったが，同時に外殼のコストも俕くなった。問題は 犾のようにして，満足に解沈された。すなわ細い均一 の，大きさの結晶䊀度とするために閒始と終了㭙の焼鈍温 展を注空深く調節し，合金内にできるだけ均一の忍的が 笖生するようにダイスの設計をしたわけである。

\section{合金の耐食性}

応打腐食割れ妾防ぐ一般的なゔ法の内 2 番目に效果的 なものは合金の選択である。応少展食割れに対する数種 の)銅会金の抵扰性の相違はすで述べた。これ性別し て次のようになる。
1）低酎食州:0) もの

a) $20 \%$ 以上の $\mathrm{Zn}$ を含毛兴銅

b) $20 \%$ 以上の $\mathrm{Zn}$ を含々, 少甾の $\mathrm{Pb}, \mathrm{Sn}, \mathrm{Al}$ 在含子鉛滇銅，ナドミラルティ黄銅，フルミ黄銅 など

2）川程率の耐食性孛もつもの

a）赤黄銅，コマーシャル青銅，ギルディングのご とく $20 \%$ 以下゙の $\mathrm{Zn}$ を含むもの

b) テルミ青銅

c) 洋白

d）燐青銅

3）问全性のもの

a) シリコン替銅

b) 燐青銅

4）非常に腹い耐食性をもつもの

a) キュプロニッケル

b) タフピッチ銅

応力腐食制れを避けるため腐食剂たる，空父，湿父， フンモニヤを金属に接触しないように努めても，あまり 効果はない。この三つのうちでTンモニヤは最もやっか いなものの゙ある。破損の原因を追求するに際し，しばし ば応力腐食割れの原因上なるアンモニヤの発生源をつき とめる研究がなされるが，これは䑤益なことである。あ るいはナンモニヤが存在しないから応力腐食割れによっ てテンモニヤは重要でないと述べられたりするが，こ机 も意味がない。実験窒の条件でTソモニヤがなくなるよ うに意図したのでないかぎり大父中には必ずアンモニヤ が存在するということは，今日では明白なことである。

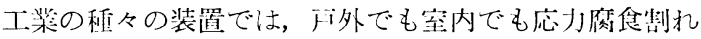
は起るばかりでなく，田園でも，海上の大父中でも起 る。最も警くべきことは家庭でも発生することだ。湿父 が多く，清掃のためごくまれにしかアンモニヤが使われ るにすぎない浴公や，台所で発生するのみならず居開で もおこる。

銅㐁金の応力腐食割れは，大きな経済的損失をひきお こすという恝味では重要なものではない。実用的見地か らの間題は，そのために十分理解されている。しかし， それは政究にとって興晰ある問題である。なぜなら，第 一に破損のドラマチックな性質，第二に，その登生機構 悹完全に理解することが非常に导ずかしいからである。

1916 Race St., Philadelphia 3, Pa.

ASTM の電着金属被覆に関する B-8 委員会 1 分科 会 $\mathrm{C}$ 班によるシンポジウムにおける 9 報文を包括した もので, その内容は歴史, 化学反応, 析出物の性質, 操 作方法, 利点亡欠占, 応用, 試験法, 特許, 参考交献上 りなっている。 